\title{
26. EFFECT OF THE SHIP'S HULL ON SEISMIC SOURCES ${ }^{1}$
}

\author{
Hartley Hoskins ${ }^{2}$
}

\begin{abstract}
In the course of preparing for a vertical seismic profile experiment on the JOIDES Resolution drilling ship at Hole 504B on Leg 148, measurements of air gun and water gun source signatures were made twenty days apart using a source monitor hydrophone suspended 142 and $102 \mathrm{~m}$ below the ship. Comparing the two data sets, it was noted that the source signatures changed. Several possible causes were considered, and the most significant change found was the emptying of one of the ship's large double-bottom fuel tanks. It is inferred that the sound impacting on the vertical port side of the ship is re-radiated by the bottom by means of the ship's framing. The amount re-radiated appears to be affected by the change in fluid level in the tank.
\end{abstract}

\section{INTRODUCTION}

High-pressure air-driven seismic sources have a complex waveform and spectra that are influenced by a number of factors, among them supply air pressure, gun depth, chamber size, and discharge port design. To account for these sources of variability better, the vertical seismic profiles (VSPs) we have performed on the JOIDES Resolution have included a small hydrophone suspended 100 to $250 \mathrm{~m}$ below the sea surface under the guns to observe a reasonable facsimile of the waveform incident on the seafloor. A source monitor situated nearer the guns does not measure the waveform similar to that incident on the seafloor because of near-field effects and the sea surfacereflected path spreading loss is significantly greater than the directly down wavefront.

In preparation for a VSP at Hole 504B on Leg 148, a Bolt PAR 1500 air gun with a 1000 in $^{3}$ chamber, and a Seismic Engineering P400 water gun with a 400 in $^{3}$ chamber were rigged on 7 and $4.6 \mathrm{~m}$ pendants, respectively, and suspended one above the other below a common float. The float was tethered to the ship's port aft (\#3) crane about $22 \mathrm{~m}$ abeam of Frame 73. Measurements of the two sources were recorded and the apparatus stored for 20 days in readiness for the experiment. After the experiment, it was noted that the source monitor measurements made during the preparations were different from those made during the experiment (Fig. 1).

\section{DIFFERENCES IN SIGNAL AND PHYSICAL ARRANGEMENTS}

Trace B of Figure 1 shows a second sharp positive pulse, similar in shape to the first one, at 10 to $12 \mathrm{~ms}$ after the first one. This delay is 2 to $3 \mathrm{~ms}$ less than the traveltime of the horizontally moving wavefront between the gun and the ship's hull. This new signal appears both in the water gun and air gun shots, indicating that it is not caused by a change in one of the sources. Several shots were recorded in each case, and the waveforms were quite uniform.

There were differences between the measurements:

1. The source monitor was suspended at $142 \mathrm{~m}$ depth for the first measurement and at $102 \mathrm{~m}$ for the second.

'Alt, J.C., Kinoshita, H., Stokking, L.B., and Michael, P.J. (Eds.), 1996. Proc. $O D P$, Sci. Results, 148: College Station, TX (Ocean Drilling Program).

${ }^{2}$ Woods Hole Oceanographic Institution, Woods Hole, MA 02543, U.S.A. hhoskins@whoi.edu
2. The ballast weight for holding the source monitor hydrophone directly below the sources was $55 \mathrm{~kg}$ initially and $40 \mathrm{~kg}$ in the second case.

3. The current speed varied diurnally and came generally from the northeast. The ship's heading did not change, but the thrust to hold position varied. There are six thwartship thrusters near the stern of the ship. Their depth ranges from 4 to $8 \mathrm{~m}$. The direction of thrust is generally only changed when the ship's heading changes, but the speed varies continuously. Sea state varied from 1 to 2 . The source monitor may have shifted a few meters in the fore-and-aft direction.

\section{SHIP FRAMING AND TANKS}

Frame 75 is major boundary between the ship's rectangular hull shape forward and the molded stern section aft. Forward of Frame 75, the frame spacing is $8 \mathrm{ft}$; aft of it, it is $2 \mathrm{ft}$. On the port side of the ship, there are seven oil or water tanks below the water line (Fig. 2; Table 1). Between the two sets of measurements, the fluid level in two tanks changed significantly:

1. The \#6 port double bottom tank was emptied, and

2. The aft peak ballast tank was emptied.

Of the two tanks emptied, the effect of emptying the \#6 double bottom is probably more significant, because of its large flat bottom area $\left(121 \mathrm{~m}^{2}\right)$, than the effect of emptying the aft peak tank. The aft peak tank is about $60 \%$ of the volume of \#6, shallower, and with more vertical than horizontal walls.

\section{DISCUSSION}

The peak pressure of the air gun signal is about 3 psi above ambient, and that of the water gun about 2 psi. The side of the ship is nearly normal to about $4 \%$ of the outgoing wavefront. The vertical area of the hull approximately normal to the horizontally propagating portion of the wavefront is roughly $180 \mathrm{~m}^{2}$.

The hull of the drilling ship is a fairly rigid structure. It is postulated that the framing may be sufficiently rigid as to flex the bottom of the ship in response to the impulsive wavefront incident on the side. The travel times do not match this model adequately to be certain.

An alternative hypothesis is that the changes in source/hull/receiver geometry noted above may have given rise to a strong reflec- 
H. HOSKINS
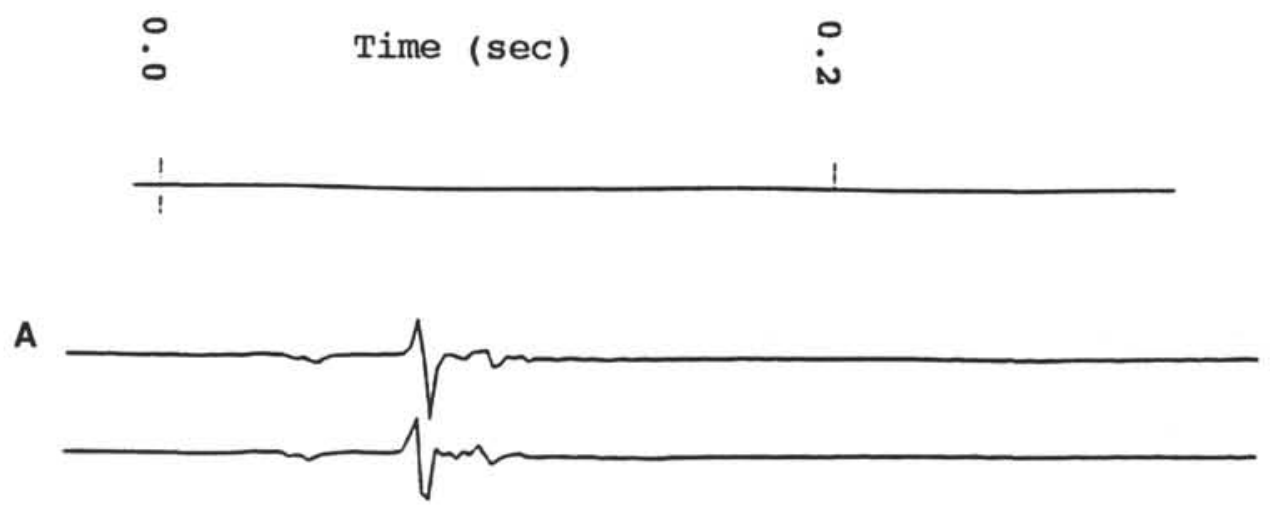

B

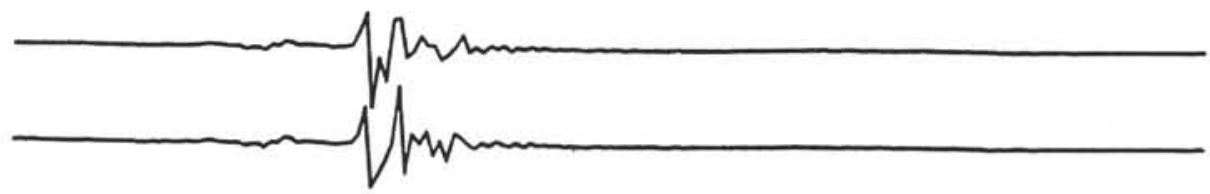

C

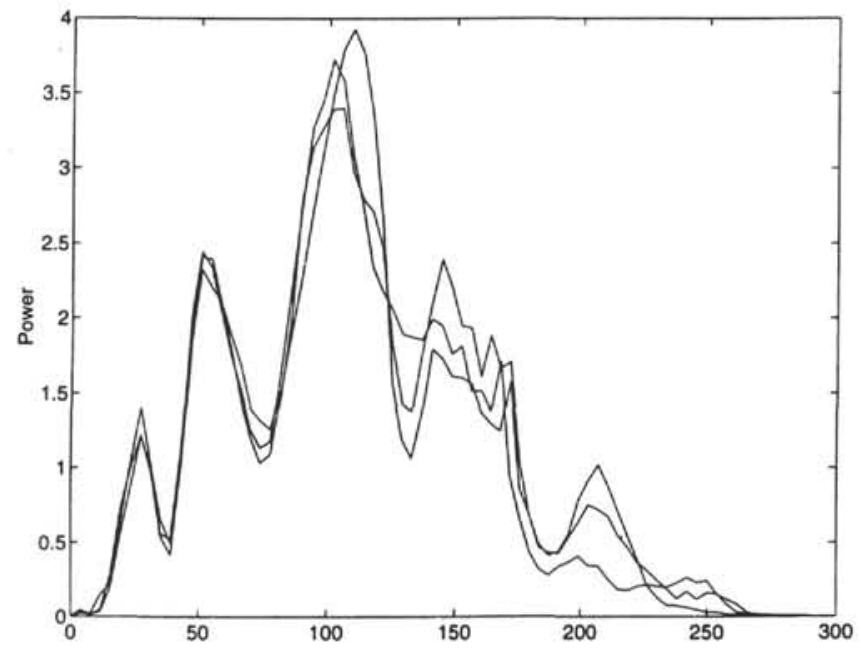

D

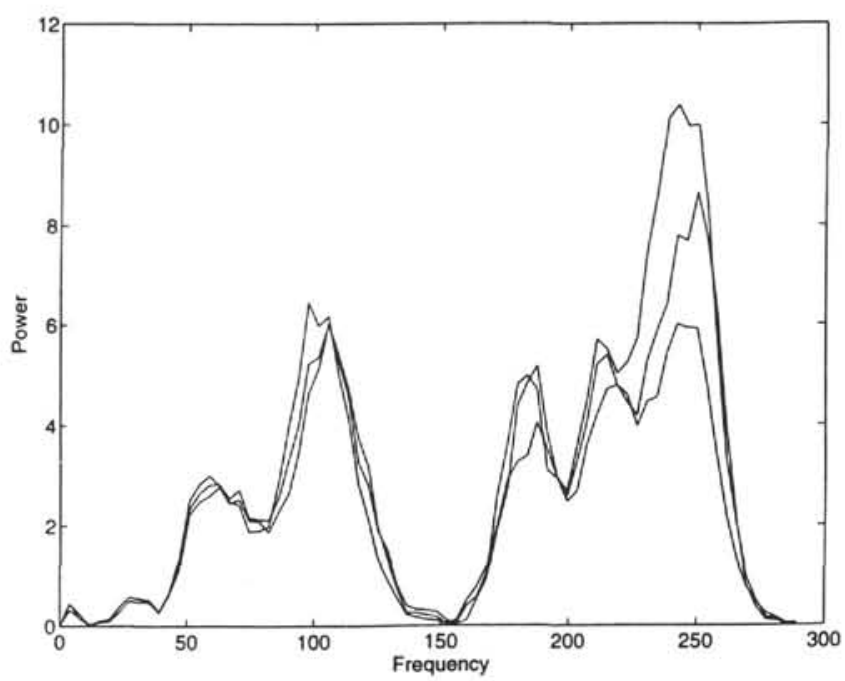

Figure 1. Comparison of pressure-time traces of water gun shots. A. 20 February 1993. B. 9 March 1993. C. Spectra of Figure 1A. D. Spectra of Figure 1B. See Table 1 for changes in the ship's tank levels. 
tion off the hull, but the change in tank content is my preferred hypothesis.

I have not found any published reports on the effect of ship hulls on seismic sources. The NTIS, SPIN, INSPEC, and GEOREF bibliographic databases were searched. Perhaps this is to be expected as the arrangement of source and monitoring hydrophone here is not that used for seismic profiling. The sources are typically towed behind the ship and the stern of the ship provides a narrower and arcuate aspect.

Based on this effect, one might consider constructing a seismic source "amplifier" by building a large flat-bottomed, stiffly framed annulus around the seismic source. The horizontally propagating portion of the wavefront would be "captured" by the inner wall of the annulus and re-radiated downward. Such an annulus could interact with as much as $50 \%$ of the wavefront depending on its draft.

\section{CONCLUSION}

It appears that for this arrangement of source and receiver that the effect of the ship's structure and tanks may be significant on the downward radiated air and water gun source signatures. This is a relevant, and perhaps needed, input to seismic signal processing.

\section{ACKNOWLEDGMENTS}

Many thanks are due Arno Jacobsen, Chief Engineer, and Christopher Nehring, BP engineer, who provided the tank level records and kindly answered all my queries. Helpful reviews and suggestions for further work from Hajimu Kinoshita, Ralph A. Stephen, and Stephen A. Swift are gratefully acknowledged.
Date of initial receipt: 19 July 1994

of acceptance: 17 February 1995 Ms 148SR-136

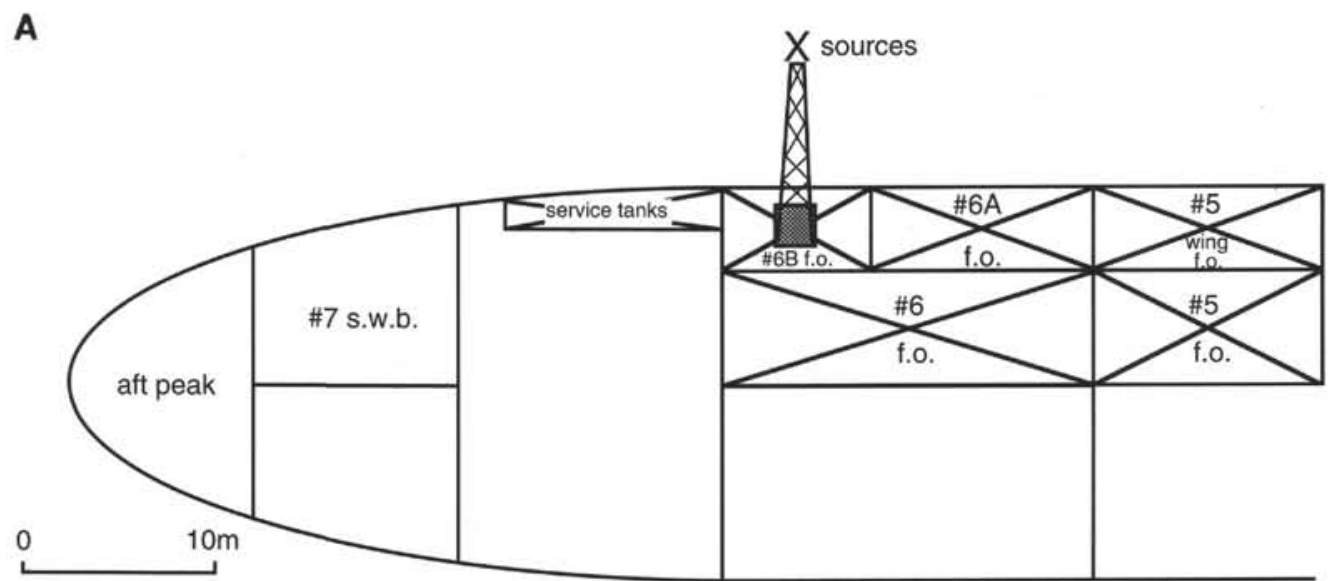

Figure 2. A. Plan view of seismic sources and tanks listed in Table 1. B. Excerpt from ship's drawings showing tanks.

Table 1. Proximal tankage.

\begin{tabular}{|c|c|c|c|c|}
\hline \multirow[b]{2}{*}{$\begin{array}{l}\text { Tank capacity } \\
\text { (U.S. gal/short tons) } \\
\text { Fore-aft frames }\end{array}$} & \multicolumn{2}{|c|}{ February 13} & \multicolumn{2}{|c|}{ March 5} \\
\hline & Sounding & $\begin{array}{l}\text { Amount } \\
\text { (U.S. gal/short } \\
\text { tons) }\end{array}$ & Sounding & $\begin{array}{l}\text { Amount } \\
\text { (U.S. gal/short } \\
\text { tons) }\end{array}$ \\
\hline $\begin{array}{l}\text { \#6 Port double bottom } \\
55,734 \mathrm{gal} / 67-75\end{array}$ & $1 \mathrm{ft} 6 \mathrm{in}$. & 14,000 & $0 \mathrm{ft} 0 \mathrm{in}$. & 0 \\
\hline $\begin{array}{l}\text { \#6A Port wing } \\
87,822 \mathrm{gal} / 67-75\end{array}$ & $16 \mathrm{ft} 5 \mathrm{in}$. & 72,000 & $13 \mathrm{ft} 6$ in. & 59,000 \\
\hline $\begin{array}{l}\text { \#6B Port wing } \\
51,534 \mathrm{gal} / 72-75\end{array}$ & $19 \mathrm{ft} 0 \mathrm{in}$. & 49.000 & $19 \mathrm{ft} 0$ in. & 49,000 \\
\hline $\begin{array}{l}\text { Port settling tank } \\
12,264 \mathrm{gal} / 75-91\end{array}$ & $5 \mathrm{ft} 3$ in. & 9,400 & $4 \mathrm{ft} 7$ in. & 8,200 \\
\hline $\begin{array}{l}\text { Port service tank } \\
13,272 \mathrm{gal} / 75-94\end{array}$ & $6 \mathrm{ft} 6 \mathrm{in}$. & 13,000 & $6 \mathrm{ft} 6$ in. & 13,000 \\
\hline $\begin{array}{l}\# 7 \text { port ballast } \\
150 \text { tons/98-115 }\end{array}$ & $10 \mathrm{ft} 6 \mathrm{in}$. & 130 & $11 \mathrm{ft} 4$ in. & 150 \\
\hline $\begin{array}{l}\text { A ft peak ballast } \\
144 \text { tons/115-130 stern }\end{array}$ & $9 \mathrm{ft} 8 \mathrm{in}$. & 80 & $0 \mathrm{ft} 0 \mathrm{in}$. & 0 \\
\hline
\end{tabular}


H. HOSKINS

B
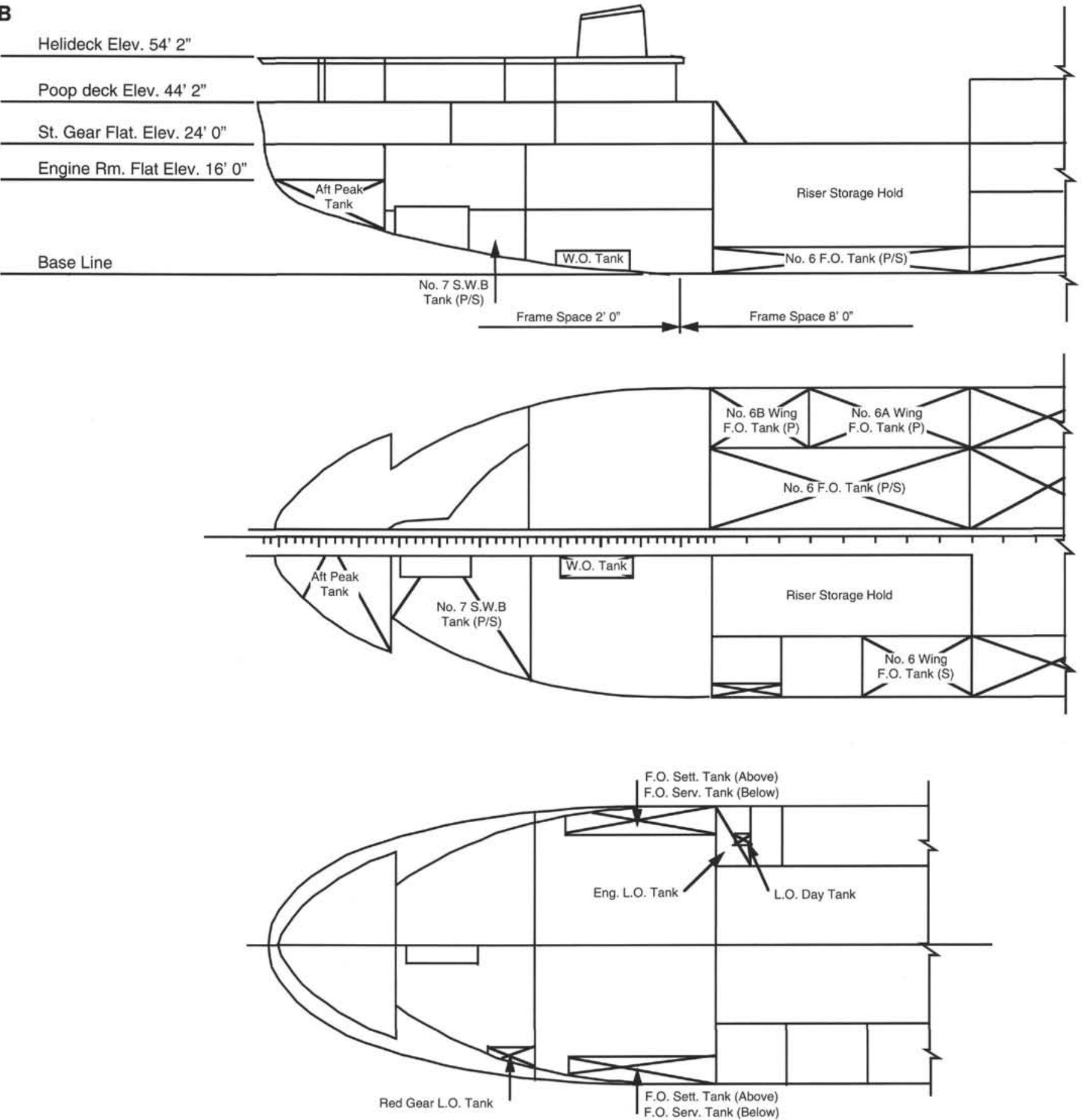

Figure 2 (continued). 